\title{
\$sciendo
}

DOI 10.2478/afepuc-2018-0011

(C) Acta Facultatis Educationis Physicae Universitatis Comenianae 2018, 58(2): 122-133

\section{BIOMECHANICAL ANALYSIS IN EQUESTRIAN VAULTING}

\author{
Martin Vaváček ${ }^{1}$, Anton Lednický ${ }^{1}$, Kristína Hajduová ${ }^{2}$ \\ ${ }^{l}$ Faculty of Physical Education and Sports, Comenius University, Bratislava, ${ }^{2}$ Gymnázium Juraja Fándlyho, Šal'a, \\ Slovakia
}

Summary: The authors focused on biomechanical analysis of the exercising shapes of the compulsory exercises in the equestrian vaulting. It is a sport sector in which similar observations have not been carried out. The use of 3D analysis brought the opportunity to observe the exercising shapes on a simulator and in real conditions on a horse. By the selected 3D approach they focused on three crucial phases of the swing back. This approach helped detect possible mistakes which the coach could not register from one position. The experimental set consisted of highly accomplished riders. The results confirmed that the higher the accomplishment level of a sportsman the fewer are the differences between the performances of an exercising shape. From the above mentioned we could assume that by including exercises on a barrel simulator into training units, we could influence the technique of performance of the individual exercising shapes on a horse in movement.

Key words: equestrian vaulting sport, biomechanical analysis, exercising shapes of the compulsory exercises, swing back, horse movement. 


\section{Introduction}

Equestrian vaulting is an independent horse riding discipline which allows the vaulters in harmony with horse to display their own individuality through the means of gymnastic and artistic exercising shapes while limited in time and space and adhering to the rules set by FEI (The International Federation for Equestrian Sports). The exercises are performed on a horse at the canter in a circle of $12-14$ metre diameter. There is a longeur in the middle of it and he/she leads the horse. There are several categories in competition: individual men, women, teams and pas-de-deux. Every category excluding pas-de-deux consists of compulsory exercises and freestyle exercises. The freestyle exercise routine is created by the competitor or the team by putting together their own exercise shapes into one unit which is completed and choreographed into harmony with preselected music.

Equestrian vaulting is one of the few sports where the quality of the sport performance and the overall result is by a great degree influenced by a living creature, specifically by the behaviour of the horse itself (obedience, "by level of riding skills" - horse's ability to perform dressage exercises at the smallest signal of the rider), its kinetic and somatic dispositions. Apart from the above the performance in equestrian vaulting is highly determined by the level of development of the speed-power abilities with great emphasis on coordinating abilities and the kinetic range of the trainee (flexibility). Each one of these abilities is tested by individual exercise shapes in the compulsory routine of which the technical criteria immediately show the inadequacies of the above mentioned abilities or inadequate technical sophistication of the sportsman.

Equestrian vaulting is one of the younger horse riding disciplines. The sport performances in this area registered a great shift forward. This progressive trend of performance brings forth the need of a deeper analysis and search for factors influencing the sport performance while at the same time determining the level of its influence. One of the areas which could help in this matter is kinematic structure of movement activity.

The development of performance in equestrian vaulting in the past was determined primarily by trainees who on the outset worked on one of the gymnastic disciplines. This was conditioned by the fact that the ability to manage most of exercising shapes of the compulsory routine in equestrian vaulting at high level was related to the level of fitness and coordinating abilities required by gymnastic disciplines. Gymnastic exercises contain a lot of similar, sometimes even identical characteristics compared to exercises in equestrian vaulting. The emphasis is in managing the movement of set exercising shapes, their number, difficulty and obviously the complexity which grows from the lowest performance level to the master level. This issue, also in consideration of the 
small number of sportsmen in this specialty, has not been dealt with proper attention and scientific research in horse riding sports has not been great overall. Just as in other sport specializations, scientific research is necessary in horse riding sports in order to understand more precisely and better the node points of the optimal technique when performing exercising shapes or when learning certain movement stereotypes. This type of analysis of technique of exercising shapes of compulsory routine was looked at closely by Vaváček \& Sklenaříková (2011), Vaváček, Hardoň \& Lednický (2012). Klouda (2010) observed the dependence of premature tilt of the upper part of body on quality of performance of the preparatory exercise of the swing back. During the practice the demanding exercises in equestrian vaulting require sequence, knowledge of node phases and their details. One of the ways how to make this process more effective is the analysis of the individual parts of the movement. In sport practice the biomechanical analysis is used primarily for this purpose (Moravec \& Slamka 1999; Cihová 2005, 2006; Lednický \& Vavák 2007).

The compulsory routine for senior teams and both categories of individuals are identical. The trainees perform 7 exercising shapes overall, out of which 3 are static (basic seat, flag, stand) and 4 dynamic (vault on, mill, scissors and swing off). Junior teams perform their simplified version. The compulsory routine in equestrian vaulting has two sections. Both begin by jumping on into astride position. The exercising shapes follow immediately one after another and despite the fact that they consist of several parts they need to be performed without interruption. Static exercises need to be held for four full strides.

Both sections of the compulsory routine begin with a mount. The mount leads to the astride position on a horse right behind the grips (Figure 1). Ideally, it consists of four phases:

1. jump-off phase,

2. take-off phase,

3. fly phase,

4. sit-down phase.

The vaulter runs parallel with longe towards the horse's shoulder. On its way towards the horse he/she begins to canter in the rhythm of horse's front legs. Prior to grabbing onto the grips his/her shoulders and side should be parallel with the horse's shoulder. Swinging up the right leg the pelvis part of the body will get higher than the head. The left leg remains stretched down from the pelvis. At the highest point the right leg is stretched down into symmetrical position with the left one on both sides of the horse and lands softly, erect and precisely into the seat with the upper body vertical. The vaulter sits erect in the deepest point of the horse's back, behind the vaulter's belt, forehead facing frontwards with legs down in contact with the horse creating a strict vertical line through the shoulders, sides and heels. Both arms have to be held to the side and stretched. The ends of the fingers have to be at the eye level. Legs are down and from the frontal view the line of 
knees, ankles and fingers creates a straight line. After finishing the static part of the exercise the vaulter grabs the grips with both hands at the same time.
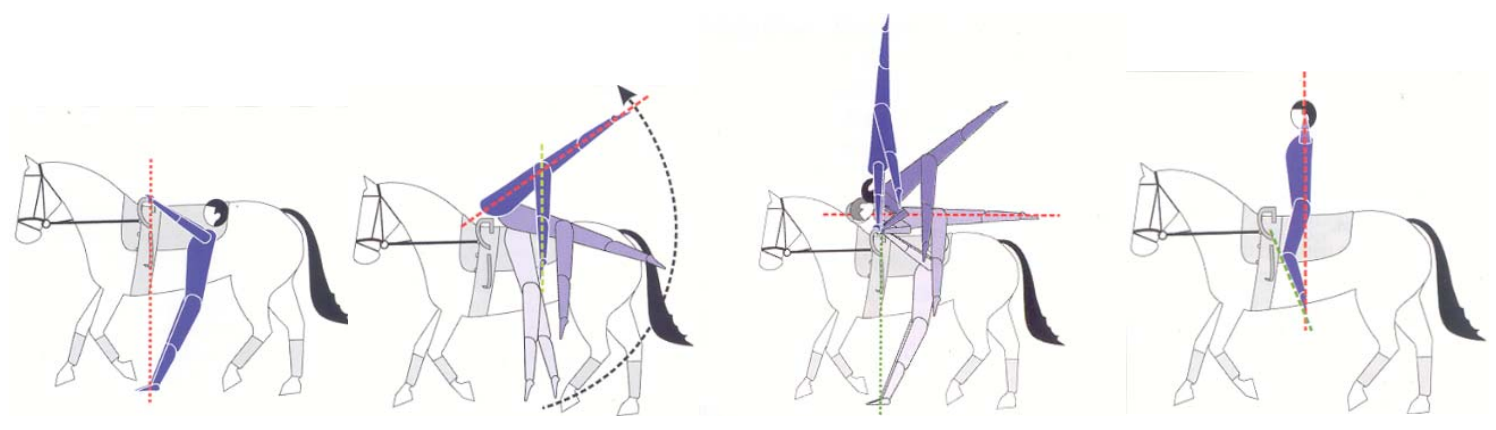

Figure 1

Illustrations of the mount into the seat (Peiler, D. \& Peiler, Ch. 2006)

\section{The aim}

The aim of this work is to contribute to clarification of kinematic indicators of movement activity of selected exercising shape of the compulsory routine in equestrian vaulting on practice simulator and in real conditions of horse riding.

\section{Hypothesis}

Based on the analysis of literary sources and empirical knowledge we assume:

H1: By the means of research, we will be able to determine, or, as the case may be to confirm basic biomechanical characteristics of selected exercising shapes of the compulsory routine in equestrian vaulting

H2: The differences in kinematic indicators during the performance of selected exercising shapes in real, dynamic conditions on a horse at the canter and static conditions on a barrel simulator will be greater among sportsmen with lower performance level.

H3: We assume that the height of the swing forward of the leg during the performance of the exercising shape of the swing back will be greater in regards to the horizontal axis on a horse in movement compared to the barrel in static conditions.

\section{Methodology of research}

Video graphical systems allow two dimensional (2D) or spacial, three dimensional (3D) analysis according to the choice of the system operator and assume the use of one (for 2D), two (a minimal precondition for 3D analysis) or more video cameras. 3D analysis is an expansion of 2D analysis (Duchoslav 2005).

During the implementation of the research we used the controlled ex post facto research. In 
order to record a selected exercising shape (the mount, the swing back) we used optoelectric analyser of the Swedish company Qualisys. The system of its use was described in detail by Soumar (2009). For the purpose of observing the movement of measured object, so not only the sportsman (Soumar, 2009) it uses high frequency video cameras (Figure 2) with the use of passive or active markers. This technology could offer spacial coordinates almost in real time (delay $7 \mathrm{~ms}$ ). The software tools which are part of the system, allow on the one hand simple calculations of basic kinematic quantities, on the other demanding complex calculations. The system uses the principle of rebound infrared light from reflective material applied to the surface of a marker attached to the moving object (Figure 3). By means of inner algorithms and infrared filter placed in front of the camera lens, the system will achieve that it registers only the reflections from the reflective material on the surface of the markers; therefore it is relatively simple to read the position of the middle of the marker on the recording medium. From the end points on the sportsman's body we could calculate the centers of gravity and by connecting these end points of position vectors we could attain trajectories of movement of the centers of gravity of the segments. The trajectories contain complex spatial information. In regards to placement, number and setting of video cameras we took into consideration tests of precision of measurement of the analyser. During the experiment we used 10 video cameras Oqus-3 (1.3 Mpx) with a shooting frequency of $120 \mathrm{~Hz}$. Each one of the cameras was connected to each other in a circle with cabling, connected with control unit in the form of PC and placed on stands in space according to the situational scheme (Figure 2).

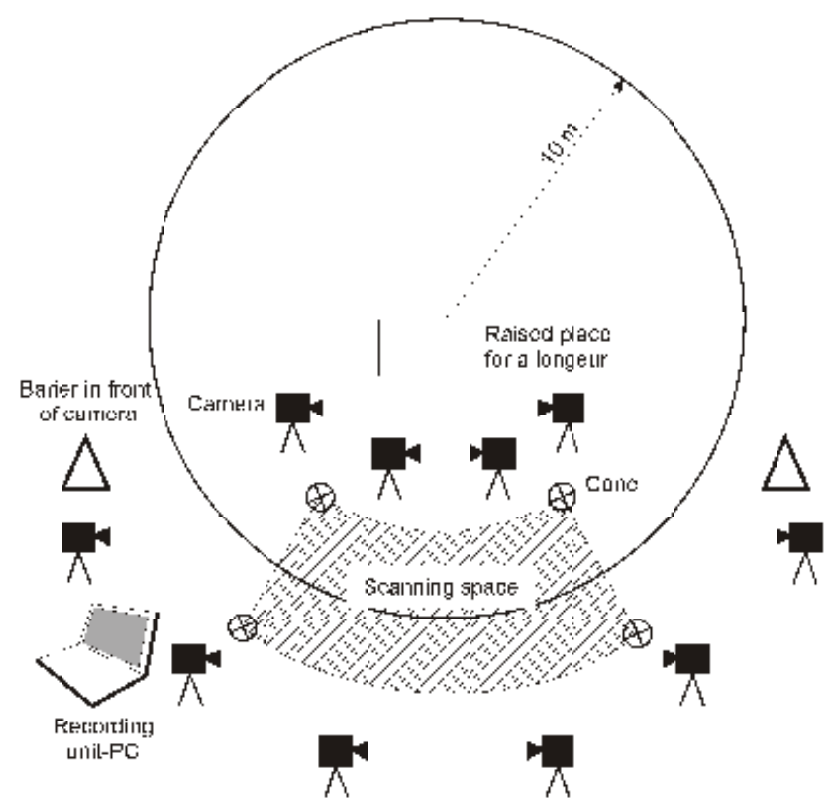

Figure 2

Situational scheme of video cameras placement, material and technical placement barrier in front of video cameravideo cameraelevated spot for longeurconearea of shooting recording unit$P C$ 


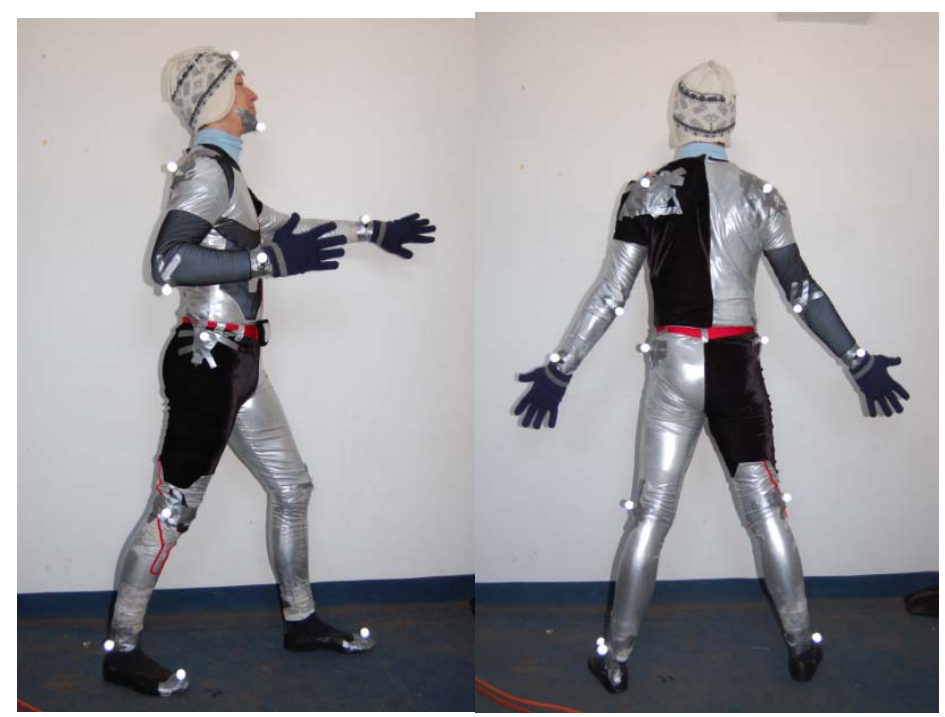

Figure 3

Recorded antropometrical points on sportsman

After placing the individual markers on the body of an experimentee the procedure of organization of the collection of data was as follows: First we placed a barrel simulator into the area of shooting, where the experimentee performed the observed exercising shape. After the removal of the simulator, followed recording of the exercise of the same experimentees on a horse During our measurement we used only one horse due to keeping the conditions standard for all the experimentees (type of canter jump, length of canter jump, height of the animal).

The above mentioned video camera setting allowed us to define the most important indicators of the observed exercising shape - the swing back. There were 21 indicators observed, out of which we evaluated two (U2 and U3) with the assumption that indicator U1 met the conditions mentioned in the chart. Chart 4 and Figure 4 state a more detailed description of the observed indicators.

Table 1

Identification of kinematic indicators of the exercising shape the swing back

\begin{tabular}{|l|l|l|}
\hline Indicator & Decryption & . Unit \\
\hline U1 & $\begin{array}{l}\text { Angle of leg against the vertical axis (the angle is created by the tip of leg - } \\
\text { coxal-vertical axis) at the moment of the leg being back horizontally (which } \\
\text { means the angle between the horizontal axis and straight line of coxal-tip of } \\
\text { leg equals zero). }\end{array}$ & $\left({ }^{\circ}\right)$ \\
\hline U2 & $\begin{array}{l}\text { Angle of leg against the vertical axis (the angle is created by tip of leg-cox- } \\
\text { vertical axis) at the moment when the leg is in its highest swing forward. }\end{array}$ & $\left({ }^{\circ}\right)$ \\
\hline U3 & $\begin{array}{l}\text { Angle of leg against the vertical axis (the angle is created by tip of leg- } \\
\text { coxal-vertical axis) at the moment when the leg is the highest while in } \\
\text { handstand (straight line cox-tip of leg). }\end{array}$ & $\left(^{\circ}\right)$ \\
\hline
\end{tabular}



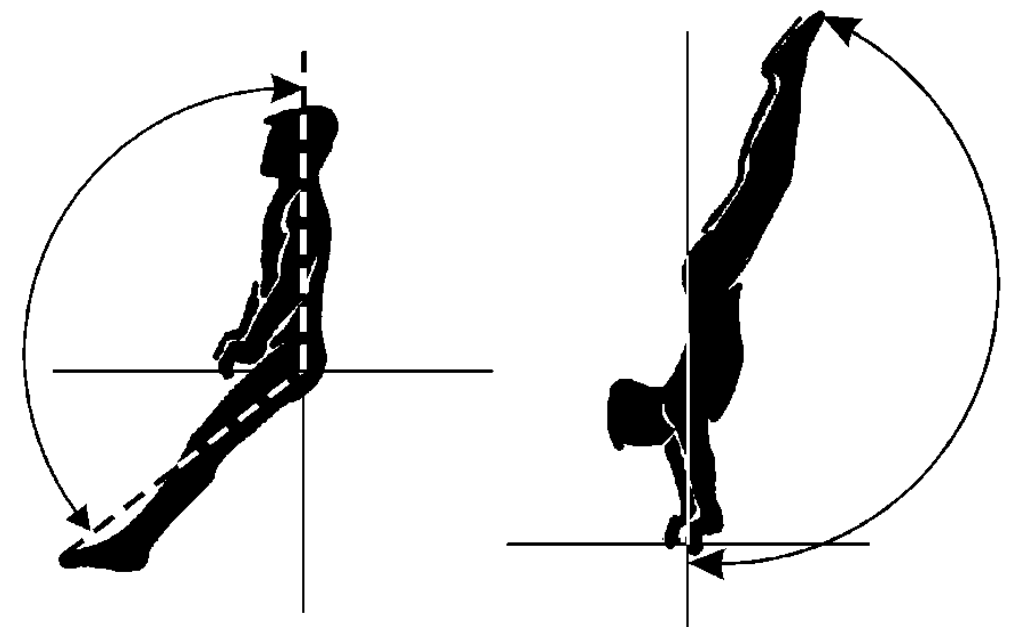

Figure 4

Indicator $U 2$ and $U 3$

\section{Ensemble characteristics}

The ensemble of experimentees consisted of 9 trainees from horse riding clubs JK Nitra Kynek, SOUP Šal'a, NZ Topolčianky, UVL Košice, Lucky Drasov, Tlumačov. The trainees (Table 2) were between 20 and 30 years old, actively involved in equestrian vaulting and representing their country at the most prestigious events in Europe and around the world.

\section{Table 2}

Basic characteristics of the observed ensemble

\begin{tabular}{|l|l|l|l|l|l|}
\hline No. & Age & $\begin{array}{l}\text { Sport } \\
\text { age }\end{array}$ & $\begin{array}{l}\text { Weight } \\
{[\mathbf{k g}]}\end{array}$ & $\begin{array}{l}\text { Height } \\
{[\mathbf{c m}]}\end{array}$ & BMI (I) \\
\hline 1 & 16 & 9 & 54 & 163 & 20,32 \\
\hline 2 & 27 & 17 & 85 & 175 & 27,75 \\
\hline 3 & 26 & 17 & 76 & 178 & 23,98 \\
\hline 4 & 31 & 17 & 75 & 180 & 23,14 \\
\hline 5 & 28 & 17 & 66 & 185 & 19,28 \\
\hline 6 & 30 & 20 & 60 & 168 & 21,25 \\
\hline 7 & 22 & 12 & 70 & 183 & 20,90 \\
\hline 8 & 26 & 14 & 66 & 178 & 20,83 \\
\hline 9 & 23 & 9 & 78 & 178 & 24,61 \\
\hline
\end{tabular}

\section{Results}

During the measurements the experimentees were not stressed by the succession of exercises or time limits as is the case in conditions of competitions. This was done in order to avoid possible 
inaccuracies. It is important to stress that during the testing of the unit of trainees which served to gain empirical material about exercising on the simulator and exercising on a horse in movement, we attempted to keep natural but primarily standardized conditions for all the experimentees.

Indicator 1 - angle of leg against the vertical axis (the angle is created by the tip of leg coxal-vertical axis) at the moment of the leg being back horizontally (which means the angle between the horizontal axis and straight line of coxal-tip of leg equals zero). This indicator is not reproduced graphically, it was the premise for evaluation of selected indicators.

Figure 5 shows the comparison of the status of indicator $\mathrm{U} 2$ - angle of leg against the vertical line (the angle is created by points: tip of leg-cox-vertical axis) at the moment when the leg is in its highest swing forward during seat on a horse and on the simulator. In our case it is about the phase of foreswing, which is important in order to gain optimal speed.

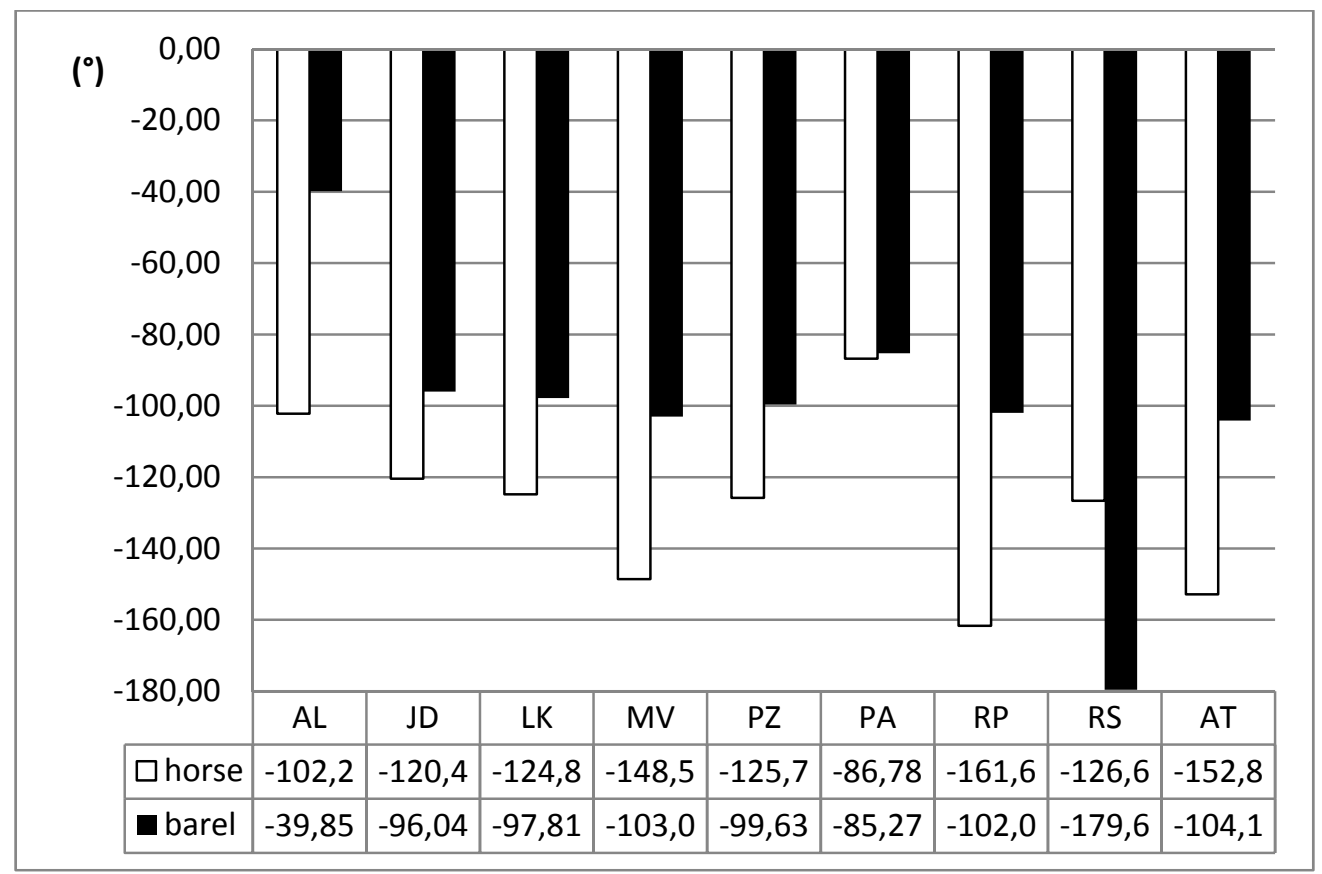

Figure 5

Comparison of status of $U 2$ on a horse and on the simulator

Body movement of any kind with the aim of high final speed begins with movement carried in an opposite way (Hochmut 1981) as in our situation depicted in Figure 5. The observed angle diminishes against the vertical axis in direct proportion to the height when putting the leg forward. It is obvious from the Figure that most of the experimentees performed the swing forward higher on the simulator than on a horse. We could clearly explain this by the fact that in static conditions an exercise requires a longer path of "run-up" of leg in the form of swifter swing followed by the acquirement of higher kinetic energy in order to manage the final position for a handstand. We believe, however, that similarly big optimal angle and slightly higher optimal angle speed of the 
simulator in both observed conditions will allow reaching the required final position of the trainee's body. From experience we know that the angle of swing forward lower than $90^{\circ}$ hinders correct timing of folding of the upper part of the body. This claim is based on experimentee P.A. with which we observed minimal differences in situations on a horse and on barrel simulator. It is possible to say that this is a proof of well managed technique (timing) in both situations. The experimentee P.A. is the world champion of 2008 in Brno and the finalist of the World horse riding games in 2010 in Kentucky (USA). Apart from comparing of the highest point of swing forward of the experimentee P.A. with other experimentees, our findings are based also on facts described by Bibler \& Drinker (2003) where they designate as mistake an overdone height of the swing forward (from our observations we consider such height to be more than $90^{\circ}$ ). The study of the authors also claims that in this part of the exercise the higher the leg gets, the more complicated is the already mentioned correct timing of folding of the upper part of the body over the grips. The authors also bring to attention that if this mistake appears during performance of this exercise on the simulator, the consequences of it will not be as extensive as in conditions on a horse in movement. The movement of the horse in this case acts against the movement of the body of trainee and makes it difficult to achieve a complete perpendicular position in handstand.

In Figure 5 we could observe the comparison of the status of U3 - angle of leg against the vertical axis (the angle is created by tip of leg-coxal-vertical axis) at the moment when the leg is the highest in a handstand (straight line cox-tip of the leg) on a horse and on the simulator. In case of most of the observed experimentees with exception of experimentees M.V., L.K. and R.S., who belong to power types of trainees and although they manage to achieve the closure of the movement of the leg in circle less technically but markedly with power which allows them to get to the required position, the handstand. We could observe that the leg reached closer to $180^{\circ}$ on a horse than on the simulator. We could therefore say that the suspension movement of the horse at canter influences in supportive way the performance of this part of the observed exercising shape the swing back. 


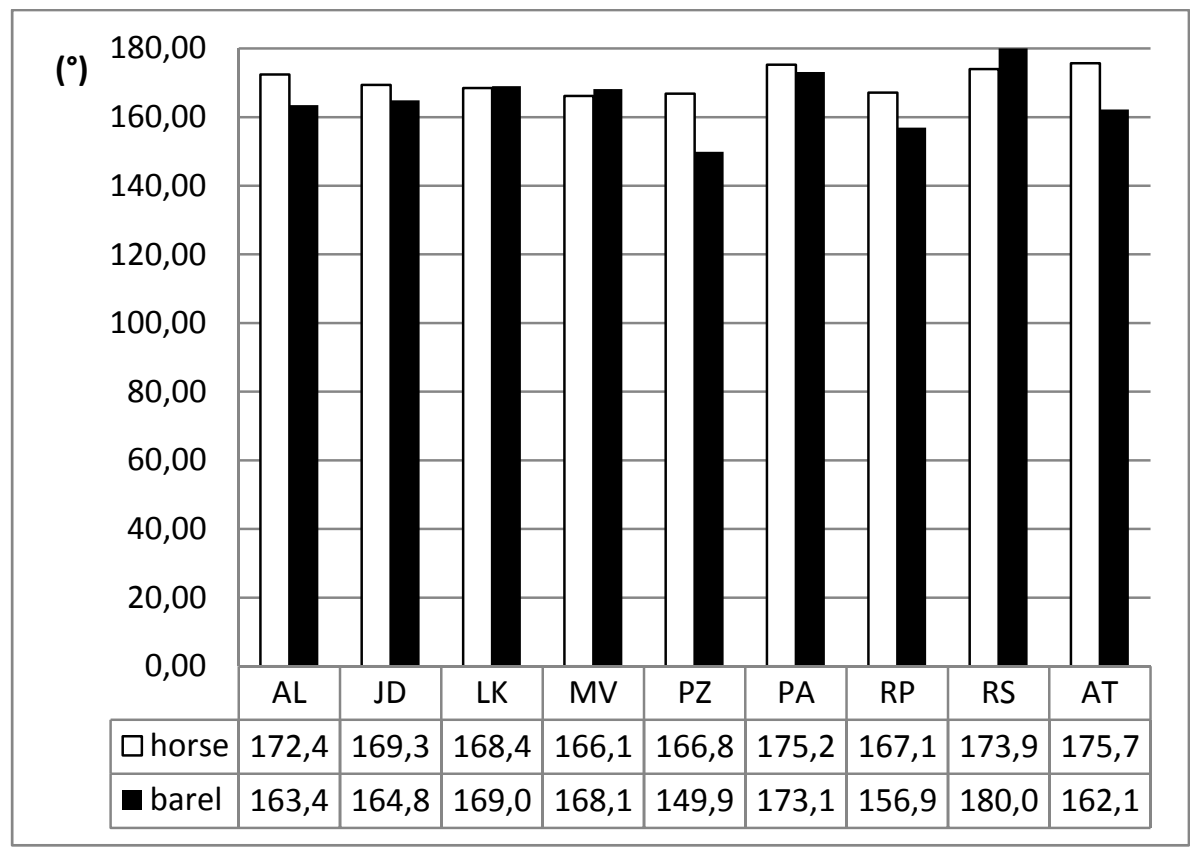

Figure 6

Comparison of state of U3 on a horse and simulator

The top trainees reach typically minimal differences in this part of the swing back on the simulator and on a horse. And they also reach the handstand position at $180^{\circ}$ in the same way in both conditions. The rare appearance of perpendicular position in our case we could ascribe to cold weather despite the fact that we attempted to warm them up sufficiently with exercise and prepare them for encumbrance.

\section{Conclusions}

In sport disciplines in which difficult exercising shapes are done in succession in a short time period, the knowledge of biomechanical parameters of the movement structure is crucial in order to reach high performance level. There is a growing need for their analyses and for search of other possibilities to work it into the training process with the aim of improving the performance of the sportsmen. By the use of biomechanical 3D analysis, we could gain not only new and deeper information about the structure of individual exercising shapes in equestrian vaulting (regarding angles, speed etc.) but we could also observe the performed acrobatic shape in detail from various angles, something that is not possible in real conditions of the training process or in competition conditions.

Biomechanical approach to solutions for the mentioned issues is based on application of principles of mechanics while taking into account the biological basis of an organism and its individual possibilities. With the help of biomechanical analysis, it is possible to observe parameters which even an experienced coach or a referee could not notice and analyse in detail. While making 
a $3 \mathrm{D}$ recording it is possible to observe the given situation from several angles which allows us more flexible and more precise diagnosis of issues and naturally offers a possibility to visually compare for example the individual attempts within a training unit or a comparison of give performance of an exercising shape with a time gap thanks to the archiving of 3D recordings of the training units. The advantages of 3D analysis in comparison to the two dimensional analysis are primarily in the possibility to observe in complexity and analyse parts of the observed techniques, observe in detail the performance of the exercises from all angles. It is possible even in such complex sport disciplines as is undoubtedly equestrian vaulting in regards to data collection and difficulty of realization of the research situation caused by the necessity to cover a great area by video camera shot. These types of conditions require professional equipment in the means of material and technical accessories and high expertise at work with recording systems as was in our case the system Qualisys. The sophistication of the technology used in our research mad the work with data easier for us since after each shot it was not necessary to process the data in a time demanding way by joining the individual anthropometric points as is the case in $2 \mathrm{D}$ analysis. The important factor becomes a high precision where one can surely count on it in this case.

The important findings for practice are the answers to our hypotheses themselves:

Hypothesis H1 was confirmed and based on the research we acquired biomechanical characteristics of selected exercising shapes from the compulsory routine in equestrian vaulting.

Hypothesis H2 was confirmed and based on the research we could say that we recorded different values on the barrel simulator in static conditions and on a horse in movement.

Hypothesis H3 was also confirmed. By researching and observing the indicator U2 we found that all experimentees reached higher values on the barrel simulator than on a horse in movement. But based on more complex observation while taking into account other factors we could say that the experienced and technically well-equipped experimentees as for example experimentees P.A. and L.K. the differences between the measured values on the simulator and a horse in movement are often minimalized. It can also be assumed from this that by implementing exercises on the barrel simulator into training units we could influence the technique of realization of individual exercising shapes on a horse in movement.

\section{References}

1. BIBBLER, I. \& E. DRINKER, 2003. Training for vaulting coaches. Compulsories and Kür. 170. 
2. CIHOVÁ I., 2006. Praktické ukážky využitia dvojdimenzionálnej analýzy pri hodnotení realizácie pohybovej činnosti trojskoku žien. Atletika 2006. Bratislava: ICM Agency. ISBN 8089257-01-1, s. 248-251.

3. DUCHOSLAV, L. Biomechanická videoanalýza pohybu. https://docplayer.net/ 37354769Biomechanicka-videoanalyza-pohybu.html.

4. KLOUDA, L., 2010. Využití kinematické analýzy pro nácvik zášsihu do stoje na rukou ve voltiži. Masarykova univerzita, Fakulta sportovních studií, Katedra kineziologie. Diplomová práce.

5. LEDNICKÝ, A. \& M. VAVÁK, 2007. Sravnenie kinematičeskogo analiza techniki bega Jolandy Čeplak i Lucii Klocovoj. Recenzovaný zborník Współczesne problemy wychowania fizycznego dzieci o młodzieży Kielce: Instytut Edukacji Szkolnej Akademii Swiętokrzyskiej. ISSN 978-83-89590-20-6, s. 60-65.

6. MORAVEC, R. \& M. SLAMKA, 1999. Závislost’ športového výkonu v skoku do výšky žien od parametrov techniky. Medzinárodná konferencia Pohyb a zdraví, Olomouc 11. - 14. 9. 1999 Pohyb a zdraví. - Olomouc: FTK UP, 1999. ISBN 80-244-0004-9.

7. PEILER C. \& D. PEILER, 2006. Optimales Voltigiertraining. 555 Übungen und Methoden vom Breiten- bis Spitzensport. 2. überarb. Auflage. Warendorf.

8. SOUMAR, L., 2009. Intraindividuální variabilita opakovaného pohybu a její indikátory při řizení motorového vozidla. Univerzita Karlova v Praze, Fakulta tělesné výchovy a sportu. Dizertačná práca.

9. SOUMAR, L., 2011. Kinematická analýza. Univerzzita J. E. Purkyně Ústí nad Labem, Ústav zdravotních studií. https://docplayer.cz/5832419-4-4-loga-barevn-p-esazet.html.

10. VAVÁČEK M., M. HARDOŇ \& A. LEDNICKÝ, 2012. Biomechanical analysis of introductory exercises swing in vaulting riding. Acta Facultatis Educationis Physicae Universitatis Comenianae, 52/l [elektronický zdroj]. - Bratislava : Univerzita Komenského, 2012. - ISBN 978-80-223-3229-3. - s. 73-77

11. VAVÁČEK M. \& J. SKLENAŘÍKOVÁ, 2011. Vplyv špeciálneho pohybového programu na rozvoj koordinačných schopností paravoltižérov. Telesná výchova \& šport. 21(1), s. 38-40. 